Winter 3-3-2011

\title{
The Need for Faculty Status and Uniform Tenure Requirements for Law Librarians
}

Carol A. Parker

University of New Mexico - School of Law

Follow this and additional works at: https://digitalrepository.unm.edu/law_facultyscholarship

Part of the Law Commons

\section{Recommended Citation}

Carol A. Parker, The Need for Faculty Status and Uniform Tenure Requirements for Law Librarians, Law Library Journal (2011).

Available at: https://digitalrepository.unm.edu/law_facultyscholarship/137

This Article is brought to you for free and open access by the UNM School of Law at UNM Digital Repository. It has been accepted for inclusion in Faculty Scholarship by an authorized administrator of UNM Digital Repository. For more information, please contact amywinter@unm.edu, Isloane@salud.unm.edu, sarahrk@unm.edu.

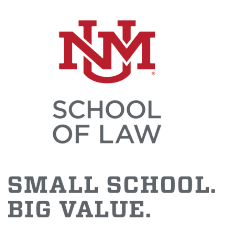

BIG VALUE. 


\title{
The Need for Faculty Status and Uniform Tenure Requirements for
}

\section{Law Librarians*}

\author{
Carol A. Parker ${ }^{* *}$ \\ Various statuses, tenure tracks, and performance review standards exist in law \\ librarian tenure or continuous appointment policies. Professor Parker argues that \\ law library leaders should insist on faculty status for librarians, develop uniform \\ performance review standards for retention and promotion policies, and support \\ scholarship with workshops and time off from administrative duties to write.
}

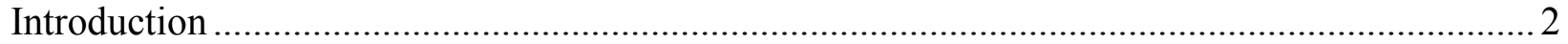

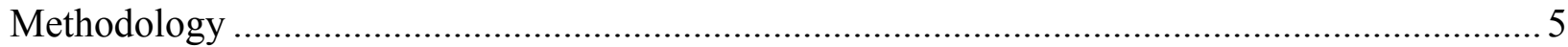

Faculty Status and Shared Governance in Law Libraries ..................................................... 6

Benefits and Responsibilities Associated With Tenure or Continuous Appointment .................. 11

Tenure-Tracks for Law Librarians: The Emergence of Separate Law Librarian Faculties ......... 19

Factors Considered in Reviewing Law Librarian Tenure Candidates ....................................... 24

Challenges Associated with Performance Review Standards ................................................. 28

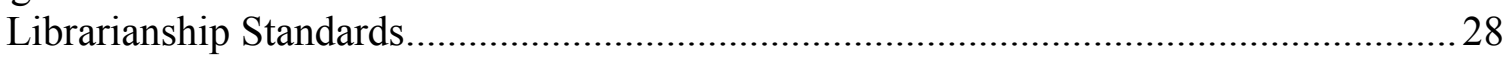

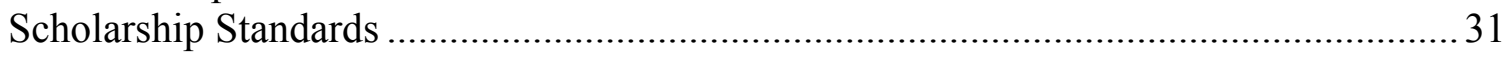

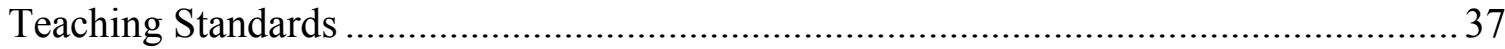

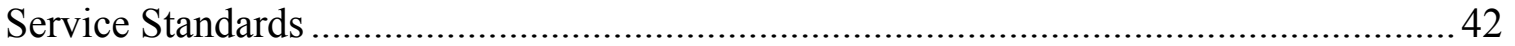

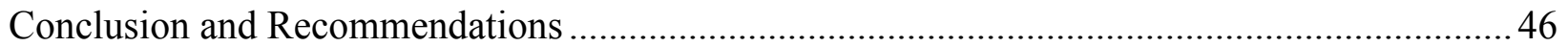

*C Carol A. Parker, 2011. The author thanks Dragomir Cosanici, R. David Myers, and Eileen Cohen for their invaluable insight and feedback throughout the process of writing this article. The author also thanks Eileen Cohen, Carolyn Kelly, Ernesto Longa, Sherri Thomas, and Theresa Strike for their research and editorial assistance.

** Professor of Law \& Associate Dean for Library and Information Technology, University of New Mexico Law Library, Albuquerque, New Mexico. 


\section{Introduction}

ף1 Literature on the subject of tenure or continuous appointment opportunities for nondirector academic law librarians primarily centers on two themes - surveys of how many law librarians have opportunities to pursue tenure or continuous appointment, and explorations of why it is personally and professionally important for law librarians to have these opportunities. ${ }^{1}$ There has been less discussion of how the possession of faculty status relates to tenure, or what performance standards should be used to review law librarians for promotion, retention, and tenure or continuous appointment decisions. Faculty status for law librarians received some attention a few decades ago, but the concept is not much discussed of late nor is it singled out as being particularly significant. ${ }^{2}$ Discussion of performance review standards tends toward brief acknowledgments that wide variations in approaches exist. ${ }^{3}$

ף2 As a profession, law librarians have not taken a clear stand on the importance of academic librarians holding faculty status, nor have they undertaken the work of

\footnotetext{
${ }^{1}$ See, e.g., James F Bailey \& Mathew F Dee, Law School Libraries: Survey Relating to Autonomy and Faculty Status, 67 LAW LiBR. J. 3 (1974); Sharon Blackburn et al., Status and Tenure for Academic Law Librarians: A Survey, 96 LAW LiBR. J. 127, 130-34, 137, 2004 LAW LiBR. J. 7 9甲 9-17, 25 (providing the most recent detailed survey to date, and also exploring more fully than ever before performance standards often found in law librarian tenure policies); Katherine E. Malmquist, Academic Law Librarians Today: Survey of Salary and Position Information, 85 LAW LIBR. J. 135, 142-43 (1993); Oscar M. Trelles II \& James F. Bailey III, Autonomy, Librarian Status, and Librarian Tenure in Law School Libraries: The State of the Art, 1984, 78 LAw LIBR. J. 605, 657-73 (1986).

${ }^{2}$ The most recent statement on faculty status for law librarians is Brian Huddleston's chapter discussing all of the various employment statuses applied to academic librarians. Brian Huddleston, Types of Employment Status for Academic Librarians, in BeYond the Books: People, Politics, AND LIBRARIANSHIP 31, 31-38 (Leslie A. Lee \& Michelle M. Wu eds., 2007). In contrast, thirty years ago faculty status for librarians was much more of a hot topic. See Dan J. Freehling, The Status of Academic Law Librarians and Faculty Status for Librarians: An Introduction, 73 LAW LIBR. J. 887, 888-90 (1980). The topic also is more developed in the general library literature. See, e.g., Thomas G. English, Administrators' Views of Library Personnel Status, 45 C. \& RES. LIBR. 189 (1984).

${ }^{3}$ See, e.g., Blackburn et al., supra note 1, at 133, ๆ 14; James M. Donovan, Do Librarians Deserve Tenure? Casting an Anthropological Eye upon Role Definition Within the Law School, 88 LAW LIBR. J. 382, 391-92 (1996).
} 
creating model policy recommendations or guidelines identifying specific performance review factors for tenure considerations. This is in contrast to positions taken by the Association of College and Research Libraries (ACRL) endorsing faculty status for academic librarians and adopting tenure policy guidelines that include specific performance review factors. ${ }^{4}$

93 This article reports data gathered in an August 2009 informal survey of law libraries that currently provide tenure or continuous appointment opportunities for academic law librarians [hereinafter 2009 Survey]. The survey results revealed that if law librarians have the ability to attain tenure or continuous appointments they are likely to hold faculty status. However, the results also showed that law libraries continue to employ widely varying performance review standards to assess librarians for tenure or continuous appointment.

ฯ4 The article begins by looking at the significance of faculty status for librarians, and discusses how that leads naturally to librarians having opportunities to attain tenure or continuous appointment. It next considers the ideal of tenured status and continuous appointment — what benefits are gained from such systems and what the implications are for librarians of the concept of academic freedom that underpins justification of tenure.

95 The article then discusses variations seen in the tenure tracks currently in use for law librarians, and looks in depth at variations in performance review standards. It

\footnotetext{
${ }^{4}$ Ass'n of Coll. \& Research Libraries, Joint Statement on Faculty Status of College and University Librarians (approved June 26, 1972; reaffirmed by the Board, June, 2007), http://www.ala.org/ala/mgrps/divs/acrl/standards/jointstatementfaculty.cfm [hereinafter ACRL Joint Statement]; Ass'n of Coll. \& Research Libraries, A Guideline for the Appointment, Promotion and Tenure of Academic Librarians (approved at American Library Association Annual Conference, June 2010), http://www.ala.org/ala/mgrps/divs/acrl/standards/promotiontenure.cfm [hereinafter $A C R L$ Guideline].
} 
identifies potentially adverse consequences to the profession that can result from employing inconsistent performance review standards. Potentially adverse consequences include weakening support for law librarians holding faculty status and being able to attain tenure; creating challenges associated with the portability of tenured status once it is obtained due to difficulties in assessing whether a lateral candidate has demonstrated a body of work sufficient to warrant tenure on another library faculty; and creating confusion over how newly emerging roles within the profession of librarianship, such as teaching formal classes within law schools, should be treated in tenure policies.

\$6 The article concludes that library directors and other leaders within the profession must insist on faculty status for law librarians and must develop more robust programs for encouraging librarian scholarship including workshops and time off from administrative duties to write. Law librarians must also make a concerted effort to employ more uniform and consistently rigorous standards for assessing performance for tenure or continuous appointment decisions.

97 It should be noted that throughout this article, the need for law librarians to have tenure or continuous appointment opportunities is taken as a given; thus, revisiting arguments for and against tenure or continuous appointment for librarians is largely outside its scope. ${ }^{5}$ Nevertheless, I hope this article will fan the flame of support for librarian tenure, in light of continuing assaults upon it.

\footnotetext{
${ }^{5}$ Nevertheless, many law school faculties seemingly remain unable to grasp why librarians should hold tenured or continuous appointments, often pointing to a lack of need for academic freedom for librarians to do their work, despite the significant research and teaching components involved in librarians' work. Because it has not automatically been given, and is often contested, there is still much debate centered on the notion of whether librarians "deserve" faculty status and tenure. See, e.g., Donovan, supra note 3. .
} 
98 It should also be noted that much of the discussion in this article is equally applicable to both tenure and other similar forms of continuous appointment. Both provide many of the same benefits and, in turn, impose many of the same burdens. ${ }^{6}$ Therefore, for the sake of readability, the term "tenure" is used to refer to both tenure and other forms of continuous appointment that require similar processes, procedures, and commitments, unless it is necessary to distinguish between the two for purposes of clarity.

\section{Methodology}

99 To inform this discussion, a review was undertaken of law librarian and general librarian literature on the topic of faculty and tenured statuses for academic librarians. Additionally, an informal survey of academic law libraries that currently provide tenure opportunities for law librarians (the 2009 Survey) was distributed to gather data on faculty status and standards and procedures currently used in tenure decisions. ${ }^{7}$ In particular, the survey asked law library directors whose institutions currently provide tenure opportunities for nondirector librarians:

(1) whether the law librarians hold faculty status;

(2) what track is used to determine their academic status and tenure opportunities, i.e., a law school skills track, a university library track, or a separate law library track; and

(3) what factors are considered in evaluating performance for tenure, e.g., librarianship, teaching, scholarship, or service?

\footnotetext{
${ }^{6}$ See infra 9 17-23 for a discussion of the differences between the two.

${ }^{7}$ The complete survey form is included as the appendix.
} 
ף10 The information gathered in the 2009 Survey builds on previous surveys on these topics, especially a 2001 survey conducted by law librarians at Texas Tech University School of Law, ${ }^{8}$ as well as data on law librarian status collected by AALL's Academic Law Libraries Special Interest Section (ALL-SIS) Continuing Status/Tenure Committee. ${ }^{9}$ The 2009 Survey generated fifty-six responses. ${ }^{10}$ These responses represent $47.5 \%$ of the libraries identified by the ALL-SIS Continuing Status/Tenure Committee in 2009 as providing tenure or some other form of enhanced employment status for nondirector law librarians.

\section{Faculty Status and Shared Governance in Law Libraries}

ף11 Librarians working in American colleges and universities began demandingand receiving - faculty status in recognition of being the equals of teaching faculties more than fifty years ago, and was particularly strong during the 1960s and 1970s. Hand in hand with achieving faculty status came attainment of more educational degrees;

\footnotetext{
${ }^{8}$ Blackburn et al., supra note 1 .

${ }^{9}$ The 2009 ALL-SIS data listed information for 182 U.S. law schools, indicating that 118 law libraries provided some form of enhanced status for law librarians (forty-three provided tenure-track opportunities; and seventy-five had some type of continuous appointment status). The data was revised in 2010 but show very little had changed. ALL-SIS Continuing Status/Tenure Comm., Academic Law Librarian Tenure and Employment Status Survey, http://www.aallnet.org/sis/allsis/cst/index.html (last updated Apr. 6, 2010).

${ }^{10}$ The survey was administered via Survey Monkey (www.surveymonkey.com) during August 2009; participation was solicited via e-mail postings to the Law Library Directors' listserv and the ALL-SIS listserv. It was deliberately kept brief to encourage participation. Responses from institutions that do not currently provide tenure or continuous appointment opportunities were deleted, as were duplications and a few responses that were started but not completed. Some answers were edited based on explanations and comments provided. For instance, a few respondents checked "other equivalent" rather than "continuous appointment" to describe their systems, but their comments and explanations indicated it would be accurate to count these as forms of continuous appointment. In other instances, references to faculty tenure-track options applicable only to library directors were eliminated in order to report data focusing on nondirector law librarians. All 2009 Survey results are on file with the author. Some of the survey results are also referenced in a companion piece to this article. Carol A. Parker, Challenges Associated with Providing Tenure and Continuous Appointment Opportunities for Academic Law Librarians, 103 LAW LIBR. J. (forthcoming spring 2011), available at http://ssrn.com/abstract=1490113.
} 
pursuit of continuing education opportunities; participation in campus governance; and opportunities to conduct original research, apply for internal and external grants, publish scholarship, and teach classes. Attaining faculty status also meant that academic librarians had opportunities to pursue tenured status. ${ }^{11}$ Today, approximately one-half of college and university librarians hold faculty status. ${ }^{12}$

ๆ12 During the same time period, academic law librarians also sought faculty status. Faculty status in turn led to opportunities to attain tenure or forms of continuous appointment. ${ }^{13}$ Over time, however, as more law schools were established, it became less likely that librarians at newer law schools would hold faculty or tenured status. ${ }^{15}$ Consequently, today only between one-quarter and one-third of law librarians report holding faculty status. ${ }^{16}$ In my survey of law libraries, which was limited to libraries that currently offer tenure or continuous appointment opportunities, nearly seventy-seven percent (43 of 56) of respondents indicated their librarians hold faculty status (see figure 1).

\footnotetext{
${ }^{11}$ See Matthew J. Simon, The Library Director's Role in Colleges and Universities Where Librarians Are Faculty, URBAN ACAD. LIBR., Fall 1987, at 20, 20-21 (discussing the additional responsibilities that accompany the pursuit of tenure for librarians with faculty status).

${ }^{12}$ See, e.g., Richard W. Meyer, A Measure of the Impact of Tenure, 60 C. \& RES. LIBR. 110, 119 n.2 (1999) (reporting that in the early 1990s just under half of colleges provided tenure for librarians); Betsy Park \& Robert Riggs, Tenure and Promotion: A Study of Practices by Institutional Type, $19 \mathrm{~J}$. ACADEMIC LIBRARIANSHIP 72, 73 (1993) (of 304 institutions surveyed, 41.1\% of academic librarians held faculty status, with the rest holding some form of "professional status").

${ }_{15}^{13}$ See Blackburn at 127-34 supra note 1.

${ }^{15}$ Huddleston, supra note 2, at 46.

${ }^{16} I d$. at 45 . Respondents to a 1991 survey indicated that the number of nondirector law librarians with faculty rank had already decreased to about one-quarter of the respondents. Malmquist, supra note 1, at 149 .
} 


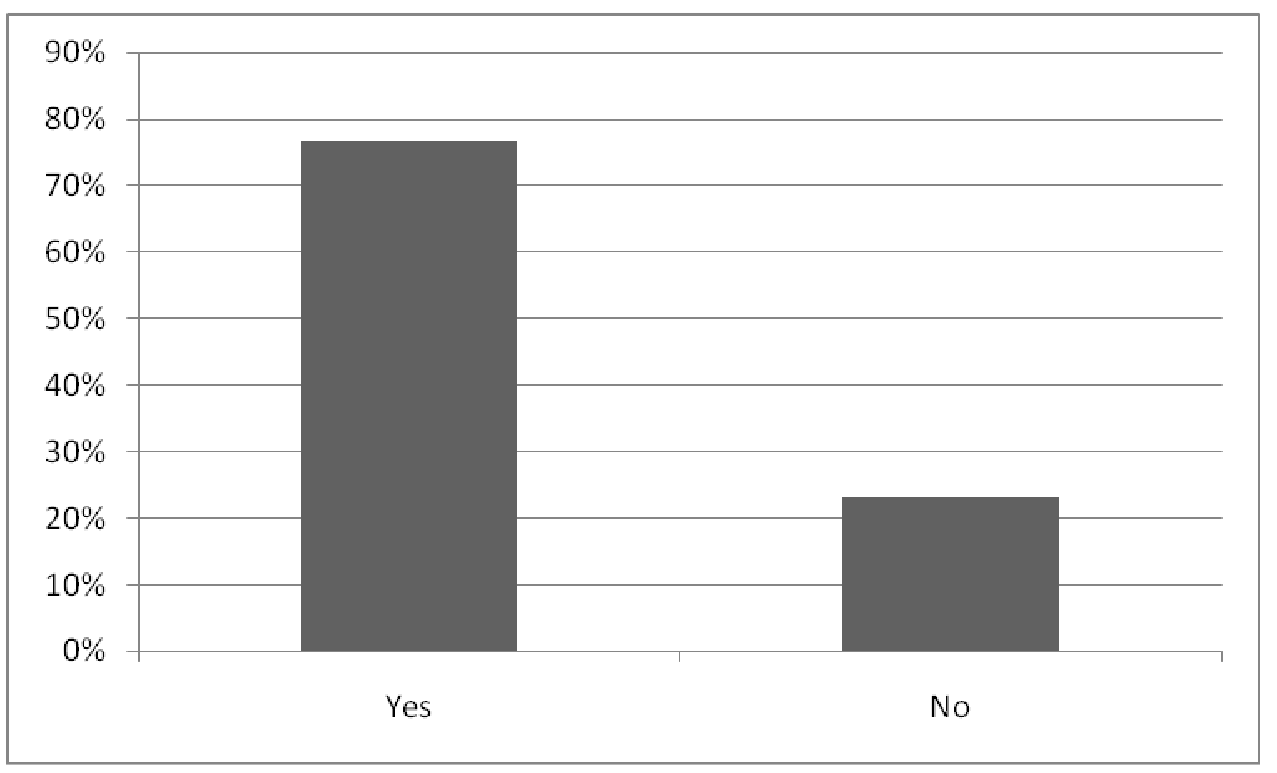

Figure $1.76 .8 \%$ of survey respondents provide faculty status to law librarians.

ף13 In the case of college and university librarians, the ACRL has taken a clear stand on the question of faculty status and unequivocally recommends that academic librarians should hold it, given the contributions they make "in the development of the institution's educational policy." ${ }^{\prime 17}$ In the case of law librarians, AALL has unfortunately not taken as strong a position on the question of law librarians holding faculty status. In a 1987 resolution on this subject, AALL called for requiring "faculty or academic status" for law librarians, leaving open the question of exactly what "academic status" might be. $^{18}$

${ }_{17}$ ACRL Joint Statement, supra note 4.

${ }^{18}$ Proceedings of the 80th Annual Meeting of the American Association of Law Libraries, Held in Chicago, Illinois, Business Sessions July 6-8, 1987, 79 LAW LIBR. J. 791, 831 (1987) [hereinafter AALL Resolution on Faculty or Academic Status]. Debate concerning the resolution language reflected concern that "academic status" was potentially ambiguous and very likely would be interpreted as something less than faculty status. The record shows that "academic status" was added as an alternative to "faculty status" because of concerns that conferring faculty status would subject librarians to the same promotion and retention requirements as the teaching law faculty. Id. at 832-33. 
\14 Faculty status for librarians is important because it expands librarian roles, making them more aware of, responsible for, and involved in the overall educational process, and raises the stature of librarians in the eyes of the teaching faculty. ${ }^{19}$ Matthew Simon wrote that faculty status for librarians reflects "administrative recognition of a central educational contribution and implies a partnership with classroom faculty" on the part of librarians. ${ }^{20}$ In some universities, by obtaining faculty status, academic librarians are able to hold ten-month appointments like teaching faculty, rather than twelve-month appointments. ${ }^{21}$ As faculty members, librarians are hired through rigorous processes similar to those undertaken to recruit teaching faculties. Librarians with faculty status participate in campus governance and have comparable criteria for retention, promotion in rank, and tenure. Tenured faculty status, of course, is also regarded as providing a high level of employment security, academic freedom for its recipients, and somewhat higher salaries. ${ }^{22}$ Additionally, law schools, universities, and the profession of law librarianship

\footnotetext{
${ }^{19}$ Freehling, supra note 2, at 889-90.

${ }^{20}$ Simon, supra note 11 , at 20 (footnote omitted).

${ }^{21}$ See, e.g., Rodney M. Hersberger, The Challenges of Leading and Managing Faculty Status Librarians, 14 J. ACAD. LIBRARIANSHIP 361, 361 (1989) (reporting on librarians at California State University).

22 See Christopher J. Hoeppner, Trends in Compensation of Academic Law Librarians, 1971-91, 85 LAW LIBR. J. 185, 192 (1993). In the late 1970s and early 1980s, demanding faculty status and tenure opportunities was a "hot" topic among law librarians, and several salary surveys from that era seemed to confirm a link between tenured faculty status and a somewhat higher salary for librarians. Id. However, a recent study of ARL libraries showed that faculty status and tenure had no effect on librarian salaries. Deborah Lee, Faculty Status, Tenure, and Compensating Wage Differentials among Members of the Association of Research Libraries, 26 Advances in Libr. Admin. and Organization 151-208 (2008). In private conversations with the author on the topic of tenured faculty status and compensation, at least one sitting law library director argued that tenure systems can actually depress librarian compensation, leading to lock-step systems that allow for little or no merit increases, or leading to trading job security for market rate salaries. For those interested in librarian compensation issues, AALL publishes a biennial salary survey of its members, and a close review of the data for academic law librarians indicates that several factors weigh in salary determinations - tenure being one of them, and the other factors being longevity at the job, whether a librarian has a J.D. degree, teaches, or supervises others. AM. ASS'N OF LAW LIBRARIES, THE AALL BIENNIAL SALARY SURVEY \& ORGANIZATIONAL CHARACTERISTICS S-3-S-29 (2009), available at http://www.aallnet.org/products/pub_salary_survey.asp (online edition available only to AALL members) .
} 
as a whole benefit from the institutional and profession service that librarians with faculty status typically contribute, often as requirements for attaining tenure. ${ }^{23}$ Along with the rewards of faculty status come expectations of participation in shared governance and peer review, professional excellence, and research and publication. ${ }^{24}$

\15 The concept of shared governance also deserves mention in any discussion of faculty status for librarians. By holding faculty status, one acquires a right to participate in the shared governance of the institution. According to the American Association of University Professors (AAUP), shared governance is "[o]ne of the key tenets of quality higher education" and "refers to governance of higher education institutions in which responsibility is shared by faculty, administrators, and trustees. ${ }^{25}$

ๆ16 However, shared governance is both a benefit and burden. Fully implemented, shared governance gives teaching faculties primary responsibility for fundamental areas such as "curriculum, subject matter and methods of instruction . . . and those aspects of student life which relate to the educational process." ${ }^{26}$ Shared governance in a library setting should give librarians a say in determining a library's mission, values, direction,

${ }^{23}$ See Huddleston, supra note 2, at 41; Simon, supra note 11, at 20.

${ }^{24}$ ACRL Guideline, supra note 4, at III.B.

${ }^{25} \mathrm{Am}$. Ass'n of Univ. Professors, Informal Glossary of AAUP Terms and Abbreviations, http://www.aaup.org/AAUP/about/mission/glossary.htm (last visited Oct. 27, 2010). The AAUP definition of shared governance also states that faculty should participate in "personnel decisions, selection of administrators, preparation of the budget, and determination of educational policies." The practical application of shared governance, however, rarely includes faculty involvement in anything more than development of the curriculum, and decisions on who to tenure, and who to promote. This can be demonstrated by perusing various university faculty handbooks.

${ }^{26}$ Id. See also ACRL A Guideline for Appointment, Promotion and Tenure of Academic Librarians, supra note 4 ("The library exists to support the teaching, research, and service functions of the institution. Thus librarians should also participate in the development of the institution's mission, curriculum, and governance. Librarians should participate in the development of policies and procedures for their library including the hiring, review, retention, and continuing appointment of their peers."). Librarians first became eligible for AAUP membership in 1956 if they held faculty status. Huddleston, supra note 2 , at 37 . 
and programming, and the ability to participate in development of policies for "the hiring, review, retention, and continuing appointment of their peers. ${ }^{, 27}$ Library directors can benefit from sharing some responsibility with nondirector law librarians. ${ }^{28}$ Shared governance should also give librarians a say in determining a law school's curriculum on legal research skills instruction, given their expertise in this area.

\section{Benefits and Responsibilities Associated With Tenure or Continuous Appointment}

\17 Holding faculty status and contributing to the shared governance of a law

library should lead naturally to law librarians having opportunities to attain tenure. AALL and ACRL both endorse academic librarians having tenured or continuous appointment status. ${ }^{29}$ Exactly what tenure encompasses, however, proves difficult to define, and many misconceptions are associated with it.

${ }^{27}$ ACRL A Guideline for Appointment, Promotion and Tenure of Academic Librarians, supra note 4.For example, library directors might invite program review by the library faculty, and work to achieve consensus among the library faculty whenever possible on programming elements. Hersberger, supra note 21 , at $364-65$.

28 "It must be the joint responsibility of management and librarians to set operational objectives and to develop programs to realize those objectives." $I d$. at 364 . However, it should be acknowledged that implementation of shared governance in a library setting can be challenging. For an in-depth discussion of the challenges librarians and their directors face in implementing shared governance see Parker, supra note 10 , at $10-14$.

${ }^{29}$ AALL Resolution on Faculty or Academic Status, supra note 18; ACRL Joint Statement, supra note 4. The 1987 AALL also called for "tenure or a form of security of position reasonably similar to tenure ...." The resolution states in relevant part:

THEREFORE BE IT RESOLVED that the American Association of Law Libraries urges universities and law schools to recognize academic law librarians as partners in the educational enterprise and to extend to them the rights and privileges which are not only commensurate with their contributions, but are necessary if they are to carry out their responsibilities; and

BE IT FURTHER RESOLVED that the Association calls on academic institutions to grant formal faculty or academic status to law librarians, either through their law faculty, law library faculty, University library faculty, or general university faculty, thereby recognizing them as professional academic employees; and

BE IT FURTHER RESOLVED that since faculty or academic status entails for law librarians rights and responsibilities similar to those of other members of the faculty, they should have proportional entitlement to promotion, compensation, leaves, and travel funds; and they should be offered a program leading to tenure or a form of security of position reasonably similar to tenure; and they should go through a similar process of evaluation and meet appropriate 
q18 Defining tenure is no easier when examined in the context of librarian roles. ${ }^{30}$

Tenure is not simply a guarantee of lifetime employment, as is commonly thought. ${ }^{31}$ As

explicated by the AAUP, tenure simply seeks to guarantee that educators will be afforded

academic freedom in their teaching and research pursuits - important components to

realizing the common good that education provides. Tenure is also a condition of

employment, providing enough economic security to make fulfillment of a faculty

member's obligations to students and society a more attractive proposition. A faculty

standards for appointment, promotion, and the grant of related benefits; and evaluative criteria should reflect the unique responsibilities of law librarians in the academic mission of the law

school ....

AALL Resolution on Faculty or Academic Status, supra note 18, at 831-32

It should also be noted that the question of faculty and tenure status for library directors, as opposed to nondirectors, has seemingly been settled, although there are continual threats to this status. See Barbara Bintliff, Update on Proposed Changes to ABA Standard 603(d): Faculty Status and Tenure for Law Library Directors, ALL-SIS NEWSLETTER, Fall 2005, at 7, 7Of course, the larger question still remains as to whether anyone - teaching faculties and librarians alike - should have tenure. As noted infra $\| \mathrm{X}$, this article assumes that tenured or continuous appointment status for law librarians is appropriate and desirable; however, that fact continues to be debated in the literature. A recent piece by Spencer Simons on the topic of law faculty tenure for library directors gives some perspective on the arguments for director faculty and tenure status, as well as the arguments against tenure generally. Spencer L. Simons, What Interests are Served when Academic Law Library Directors are Tenured Law Faculty? An Analysis and Proposal, 58 J. LegAL Educ. 245 (2008). See also Donovan, supra note 3, at 390; Huddleston, supra note 2, at 43 n.27.

${ }^{30}$ The 1987 AALL resolution did not attempt to define tenure, but the Association of College and Research Libraries (ACRL) provides this definitional statement referencing academic librarians: Tenure, or continuous appointment, is defined as an institutional commitment to permanent employment to be terminated only for adequate cause (for example, incompetence, malfeasance, mental or physical disability, bona fide financial exigency) and only after due process. Tenure (continuous appointment) shall be available to librarians in accordance with provisions for all faculty of the institution.

ACRL Guideline, supra note 4, at III.A.

31 "Faculty tenure in higher education is, in its essence, a presumption of competence and continuing service that can be overcome only if specified conditions are met. Faculty tenure is similar to civil service protection and to judicial tenure. It is not a lifetime guarantee of a position." Donna R. Euben, Tenure: Perspectives and Challenges (Oct. 2002), http://www.aaup.org/AAUP/protect/legal/topics/tenure-perspectives.htm. 
member is expected to give something, and continue to give something on an ongoing basis, in return for receiving tenure. ${ }^{32}$

q19 It is important to understand how this link between tenure and academic

freedom potentially affects librarians when they seek to justify having tenure opportunities on par with teaching faculties. Academic freedom protections apply to research, teaching, faculty governance responsibilities, and extramural speech ${ }^{33}$-all of which librarians often engage in - yet some have argued academic freedom is not necessary for the work of law librarians. James Donovan specifically took up the question of whether academic freedom is needed for the exercise of librarianship. He argued that it

${ }^{32}$ The most influential statement concerning academic freedom and tenure to date - the statement that is referenced in most modern university faculty handbooks and governance documents - is the American Association of University Professors' 1940 Statement of Principles on Academic Freedom and Tenure which has this to say about the need for academic freedom and tenure:

The purpose of this statement is to promote public understanding and support of academic freedom and tenure and agreement upon procedures to ensure them in colleges and universities. Institutions of higher education are conducted for the common good and not to further the interest of either the individual teacher or the institution as a whole. The common good depends upon the free search for truth and its free exposition.

Academic freedom is essential to these purposes and applies to both teaching and research. Freedom in research is fundamental to the advancement of truth. Academic freedom in its teaching aspect is fundamental for the protection of the rights of the teacher in teaching and of the student to freedom in learning. It carries with it duties correlative with rights.

Tenure is a means to certain ends; specifically: (1) freedom of teaching and research and of extramural activities, and (2) a sufficient degree of economic security to make the profession attractive to men and women of ability. Freedom and economic security, hence, tenure, are indispensable to the success of an institution in fulfilling its obligations to its students and to society.

AM. Ass'N OF UnIV. Professors (AAUP), 1940 Statement of Principles on Academic Freedom and Tenure, in POLICY DOCUMENTS AND REPORTS 3 (10th ed. 2006) (emphasis added; footnotes omitted). See also Richard A. Danner \& Barbara Bintliff, Academic Freedom Issues for Academic Librarians, LEGAL REFERENCE SERVICES Q., vol. 25, no. 4, 2007, at 13, 16-19 (outlining the requirements of tenure).

${ }^{33}$ Accreditation Policy Task Force, Am. Bar Ass'n, Report of Special Committee on Security of Position 13 (May 5, 2008), available at www.abanet.org/legaled/committees/subcomm/Security\%20of\%20Position.doc.. 
may not be, and that if tenure only provides law librarians with economic protection, then their demands for tenure amount to nothing more than hollow arguments. ${ }^{34}$

q20 The lesson to take from this is the importance of law librarians engaging in faculty governance, publishing, and if possible, teaching, if they are to hold tenured status. Granted, some authors, including Donovan, try to escape this conclusion by arguing that librarianship by itself is sufficiently similar to the contribution to the educational process that teaching faculties make. One example offered in support of this argument is that reference desk service, properly done, is informal instruction by another name. ${ }^{35}$ Yet even in making this argument, Donovan acknowledges that the more librarians diverge from the requirements of teaching faculties, the more they risk being assigned "hollow" faculty status or becoming ineligible for tenure. ${ }^{36}$

q21 Complicating the picture is the fact that a number of institutions provide continuous appointment opportunities for law librarians instead of tenure. Having a continuous appointment has been explained by Brian Huddleston as having "an employment contract that states the terms and conditions of service. The contracts also

\footnotetext{
${ }^{34}$ Donovan, supra note 3, at 391-97. See also Huddleston, supra note 2, at 38-39 (arguing that if librarians teach research effectively, then they do not need the protection afforded by academic freedom and tenure because teaching a skills class is objective work, and not equivalent to the work of doctrinal teaching faculties who might be working to define the principles of their discipline). But see Barbara Bintliff, The Roles and Status of the Academic Law Library Director, in THE LAW SCHOOL LIBRARIAN'S ROLE AS AN EDUCATOR 121, 130 (2008) (listing reasons why academic law library directors require tenure). Bintliff has also argued that academic freedom is necessary for academic librarians in any case. Id. ("Providing information resources to support new initiatives is equally controversial, as librarians well know.").

${ }^{35}$ See Donovan, supra note 3, at 396.

${ }^{36} I d$. at 386.
} 
often provide some level of presumption that they will be renewed and specify that nonrenewal or dismissal can only occur under specific, limited circumstances.",37

q22 The status of librarians with continuous appointments can be less than clearcut. Evidence of this is seen in the wide range of vocabulary used by those who appended comments to the 2009 Survey to describe statuses other than tenure: "continuing appointment," "employment security status," "term appointment," "extended term contract," "long term contract," and "permanent status." Continuous appointment status is also sometimes associated with nonfaculty statuses described as "academic staff" or "professional staff"- - something less than faculty status but more than at-will employment status. Teaching faculties may interpret such labels, which do not fit within their vocabulary of faculty status and tenure, as indicative of a status inferior to their own. ${ }^{38}$

q23 It is not clear whether there is any attempt made in situations of continuous appointment statuses other than tenure to link librarian roles with a need for academic freedom protections. If not, it implies that continuous appointments might also require less in the way of the responsibilities and burdens that relate to academic freedom guarantees and faculty status. Conversely, however, some librarians who hold these more ambiguous statuses are expected to demonstrate the same level of accomplishment as librarians on a more traditional tenure track in order to obtain a continuous appointment. In fact, some continuous and permanent appointments are actually associated with faculty

\footnotetext{
${ }^{37}$ Huddleston, supra note 2, at 35.

${ }^{38}$ In fact, Brian Huddleston has described continuous appointments as less prestigious than tenure appointments. $I d$. at 35 .
} 
status, ${ }^{39}$ and ACRL and AAUP statements defining tenure use the idea of "continuous appointment" to explain part of what tenure represents. ${ }^{40}$

q24 In general, about one-quarter of law librarians currently report having opportunities to achieve tenured status at their institutions. Roughly another forty percent have opportunities to secure some form of continuous appointment. The remaining onethird simply work as at-will employees. ${ }^{41}$

q25 In the 2009 Survey, which was limited to libraries that already provide tenure or continuous appointment opportunities, more than $55 \%$ of respondents indicated that law librarians at their law schools could obtain tenured status (31 of 56). The other $45 \%$ could obtain a form of continuous appointment (25 of 56) (see figure 2).

${ }^{39}$ In some respects, forms of continuous appointment solve one of the problems associated with tenurethe fear that faculty will "retire on the job" without repercussion - by providing opportunities for continuous, periodic, meaningful review after permanent employment status is obtained. See Simons, supra note 29 , at 249-50 (briefly describing the arguments against tenure generally). Arguably, though, the level of scrutiny and analysis is different when deciding whether one should get another three or five years under a continuing appointment system, versus whether one should get what is essentially a life-time appointment. Which approach is preferable or more rigorous is debatable.

${ }^{40}$ ACRL Joint Statement, supra note 4; Am. Ass'n of Univ. Professors, supra note 25 (using the term "continuous tenure").

${ }^{41}$ Huddleston, supra note 2, at 32; Academic Law Librarian Tenure and Employment Status Survey, supra note 9. 


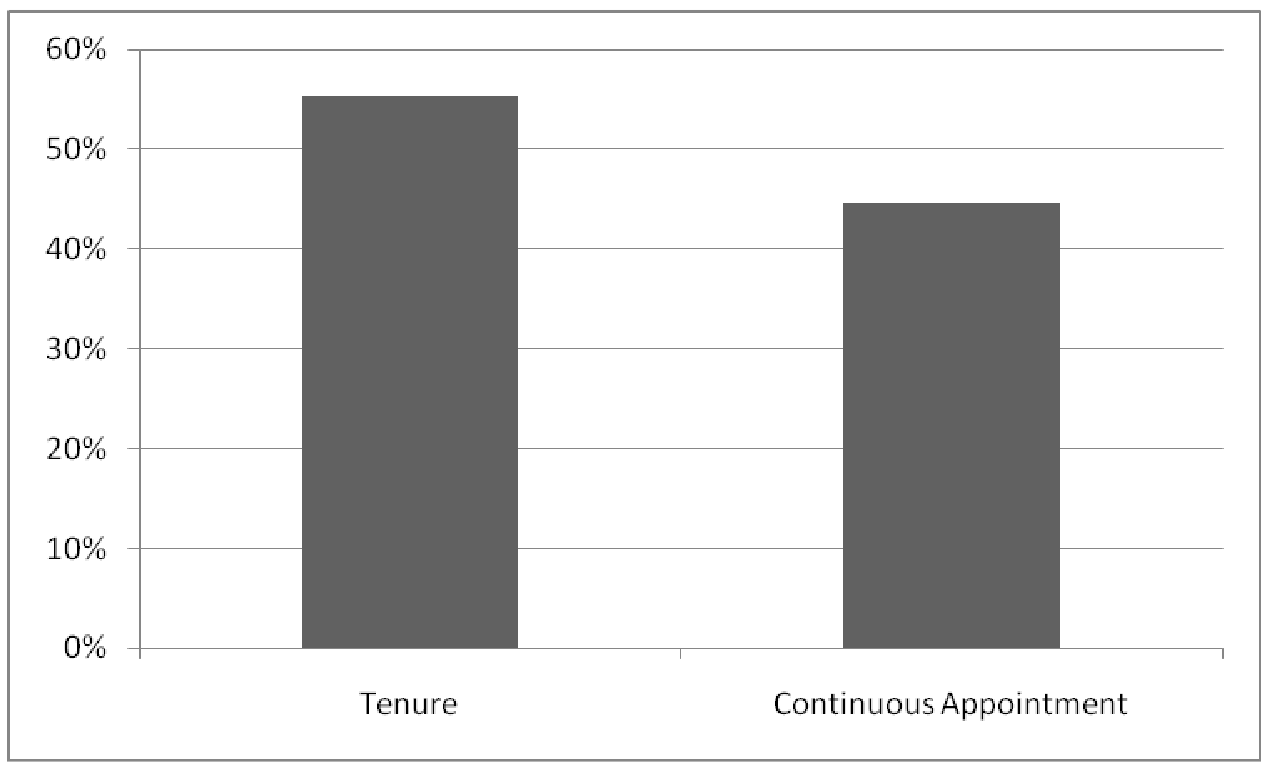

Figure 2. $55.4 \%$ of survey respondents offer tenure opportunities; $44.6 \%$ offer continuous appointment opportunities.

I26 Notably, the thirty-one libraries responding to the survey that offer librarians a tenure track also regard librarians as faculty members. The fact that their librarians, who can obtain tenure, all hold faculty status is not surprising, given that traditionally one must be a faculty member in order to pursue and hold tenure in its fullest expression. However, there was no corresponding clear association between librarians holding another form of academic status and holding continuous appointment rather than tenure. Of the twenty-five libraries responding to the 2009 Survey that provide librarians with a form of continuous appointment, twelve (48\%) give law librarians faculty status, and thirteen $(52 \%)$ do not. ${ }^{42}$

\footnotetext{
${ }^{42}$ It should be noted that references to faculty status in this article refer to library faculty status or university faculty status that is made available to librarians. As is mentioned infra $\uparrow 29$, librarians other than directors rarely hold law faculty status.
} 
927 It is also notable that all of the respondents indicated their law schools are affiliated with a university as opposed to a stand-alone law school. This may reflect broader acceptance of the concepts of faculty status and tenure for librarians employed by universities. It is also consistent with the Texas Tech law librarians' survey results, which showed a correlation between tenure and affiliation with the Association for Research Libraries (ARL). In the 2001 Texas Tech survey, half of ARL-affiliated law library respondents offered tenure or continuous appointment opportunities to their law librarians - a figure that is much higher than for academic law libraries overall. ${ }^{43}$

q28 If one parses all of the distinctions between the various labels currently used to describe law librarian status — faculty status, academic status, academic staff, professional staff, tenure, and continuous appointment—it is clear that what holds the most import for law librarians is faculty status. One can quibble about the differences between tenure and other forms of continuous appointment, but what is inescapable is the fact that only when law librarians hold faculty status can they claim a right to participate in the shared governance of the institution. Shared governance gives law librarians the ability to have a say, not only in library policies and procedures, but also arguably in the development of a law school's educational program, particularly with respect to legal research instruction, to the great benefit of both the law faculty and law students. Participation in shared

\footnotetext{
${ }^{43}$ While reviewing the various surveys of both general collection academic librarians as well as academic law librarians, the Texas Tech librarians were struck by the fact that while about one-third of nondirector law librarians had tenure opportunities, about three-fourths of the ARL-member college and university librarians enjoyed tenure opportunities. Blackburn et al., supra note 1 , at $134, \uparrow 16$. The Texas Tech survey indicated that tenure and continuous appointment opportunities at ARL-affiliated law libraries exceed the one-third figure reported for academic law libraries overall-nearly $40 \%$ of the ARL-affiliated law libraries responding to the Texas Tech survey provided tenure opportunities to their nondirector librarians. Blackburn et al., supra note 1, at 136-37, \23, 25.
} 
governance requires the protections afforded by the concept of academic freedom, and thus leads naturally to the protections of a tenure system.

\section{Tenure-Tracks for Law Librarians:}

\section{The Emergence of Separate Law Librarian Faculties}

q29 Nondirector law librarians typically follow one of three paths to tenured or continuous appointment status: (1) a separate law school track for law librarians; (2) a university librarian track; or (3) a separate law school faculty track for clinicians, legal writing teachers and other skills instructors. ${ }^{44}$ The 2009 Survey showed that separate law librarian tracks predominate among survey respondents-nearly $59 \%$ (33 of 56) of them provide tenure or continuous appointment options via a separate law library faculty track. Another $37.5 \%$ (21 of 56) provide tenure opportunities via a university librarian track. Only two respondents (3.6\%) indicated that law librarians may pursue tenure on a law school track linked with practice, skills, or clinical instruction. None of the 2009 Survey respondents indicated that their law librarians have an opportunity to pursue tenure or continuous appointment on a regular law faculty teaching track, which would conceivably require that librarians meet the same standards as teaching law faculty members. While this latter approach is common for law library directors, it was universally rejected by survey respondents for nondirector law librarians (see figure 3 ). ${ }^{45}$

\footnotetext{
${ }^{44}$ Previous surveys reported the first two options. Hoeppner, supra note 22, at 192, and Trelles \& Bailey, supra note 1, at 657-5; the third option of using a law school skills track was reported by two of the 2009 survey respondents

${ }^{45}$ As previously noted, the question of a tenure track for law library directors has seemingly been resolved for the time being, with tenure on the regular law teaching faculty track predominating. Simons, supra note 29, at 246 n.3. See also John Makdisi, Improving Education-Delivery in the Twenty-First Century: The Vital Role of the Law Librarian, 95 LAW LIBR. J. 431, 433, 2003 LAW LIBR. J. 32, 8 (emphasizing the need for academic law library directors to be faculty members). But
} 


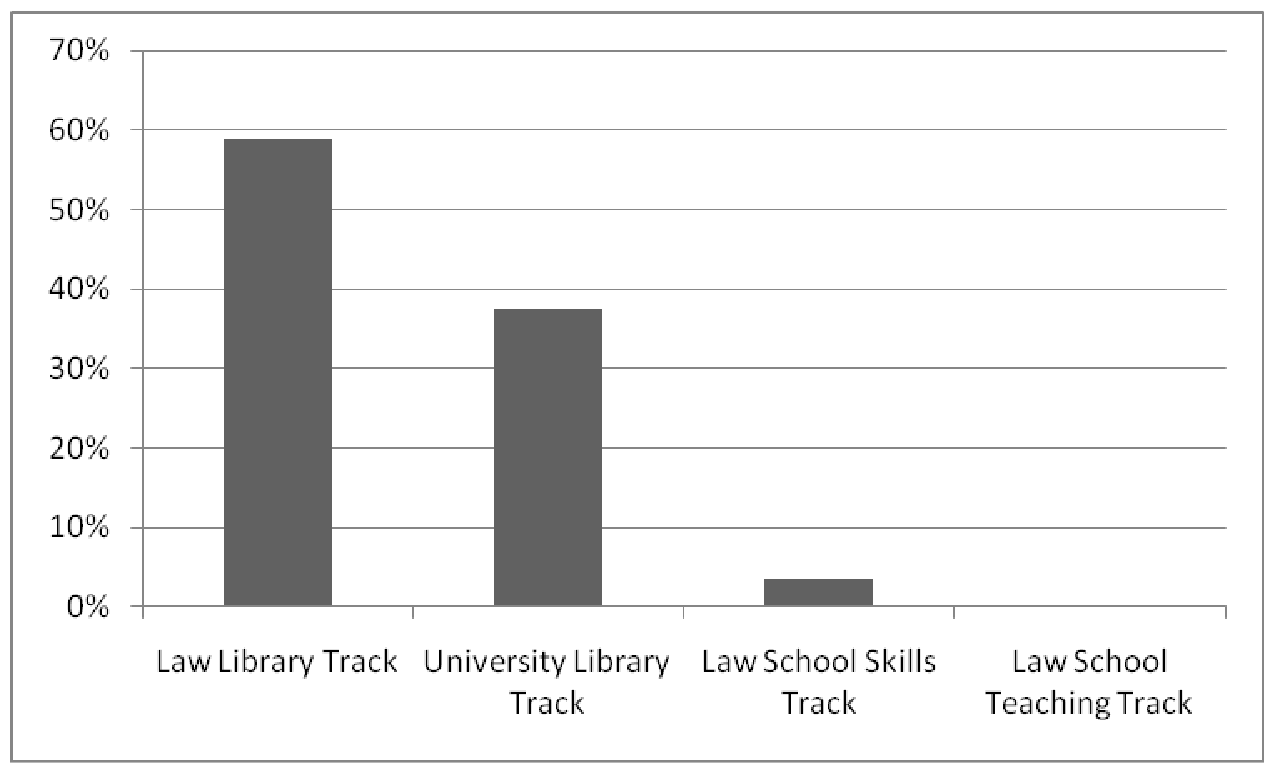

Figure 3. $58.9 \%$ of survey respondents use a separate law library tenure track; $37.5 \%$ use a university library tenure track; and 3.6\% use a law school skills or practice track. None of the respondents provide an opportunity for librarians to pursue tenure on the law school teaching faculty track.

ฯ30 Challenges are associated with each of the three approaches. With respect to a law faculty skills or practice track, on the one hand librarians may be a good fit for the skills tracks seen in some law schools, particularly if they teach legal research classes, or if librarianship is equated with other practice, clinical, or skills roles that can exist within a law teaching faculty. On the other hand, there is a potential disadvantage for law librarians who do not teach in formal law school classes if the informal instruction librarians provide, or other work devoted to technical or electronic services or collection development, is not equated with the contributions made by those who formally teach. Such an approach might potentially create different statuses of librarians within the

see Bintliff, supra note 29, at 7, describing continuing threats to law library directors' ability to hold law faculty and tenured status. 
library, with librarians who teach formal law school classes able to pursue tenure, and those who do not formally teach unable to do so. It is hard to know if use of a law school skills track in the two instances reported in the survey represent special accommodations made for individuals who warranted extra effort on the part of the law school to keep them at their institutions, or if use of a law school skills track represents an emerging trend that will become increasing common as more and more academic law librarians teach formal legal research classes.

\31 The alternative approach of using separate library tracks presents other problems, however, including reinforcement of differences between librarians and teaching faculties. ${ }^{46}$ Nonetheless, this approach is taken by most law school libraries. Virtually all of the 2009 Survey respondents indicated tenure or continuous appointment status was attained by following a librarian track, either a university library track, or a separate law library track.

१32 Following a university library track can cause concern that the law library could be forced to yield some autonomy over operations, ${ }^{47}$ although ABA accreditation standards recommend that law libraries be under the control of law school deans rather than university library deans. ${ }^{48}$ Law librarians also may resist being held to university

\footnotetext{
${ }^{46}$ Dan Freehling made this point during discussion at an ALL-SIS panel discussion in 1980. Freehling, supra note 2, at 888 ("Where does a description such as 'librarian with rank of assistant professor' fit in all of this? I mean you never read job descriptions that say, 'historian with rank of . . ."').

${ }^{47}$ Blackburn et al., supra note 1, at 133, 912.

${ }^{48}$ ABA SECTION OF LEGAL EDUC. \& ADMISSIONS to THE BAR, 2010-2011 STANDARDS FOR APPROVAL OF LAW SCHOOLS 41 (Standard 602(a)), available at http://www.abanet.org/legaled/standards/standards.html (“A law school shall have sufficient administrative autonomy to direct the growth and development of the law library, and to control the use of its resources.").
} 
library tenure requirements that might not recognize the specialized nature of law librarianship. ${ }^{49}$

\33 Perhaps as a result of such concerns, the approach taken by nearly $59 \%$ of the 2009 Survey respondents was to create a separate law librarian tenure track. ${ }^{50}$ Yet the survey revealed a good deal of variation in the implementation of the concept, as shown by a number of comments:

- 'We have a 'law library faculty' similar to the university library faculty. I pretty much copied our regulation from theirs."

- "Our documents are part of the law school but we have academic professional status, as do all librarians throughout the greater university."

- "The law librarians do not have their own promotion and tenure committee. We are handled by the law school P \& T [Promotion and Tenure] committee, of which we are not members (even though we are tenured, full professors)."

${ }^{49}$ See Joyce A. McCray Pearson, The Director and Law School Librarian's Role as Educator, in THE LAW SCHOOL LIBRARIAN's ROLE AS AN EDUCATOR, supra note 34, at 31, 34 (describing specialized nature of law librarianship and differences from general academic librarianship).

Involving law librarians with university library promotion and tenure tracks can lead to complicated relationships. One 2009 Survey respondent stated:

This is a lousy system. The university's [library system] is headed by the dean of libraries ... Although the law library is supposedly administratively independent, and is in most respects, this arrangement effectively gives the dean of libraries the ability to fire law librarians, who are hired and report through the director to the law school dean. The dean of libraries can and does override the decisions of the library college P\&T committee, creating considerable difficulties. The dean of libraries also uses this arrangement to perpetuate the misapprehension around the university that the law school somehow is within her jurisdiction. This arrangement should be avoided whenever proposed.

One other commentator was not as critical, but hoped to move away from a university librarian track over to a law school track: "We are pursuing autonomy from the university library. If that succeeds, the answer to this question will be 'law school other faculty track'."

${ }^{50}$ This development has been tracked by previous surveys during the past forty years. See Blackburn et al., supra note 1 , at $133, \uparrow 12$. 
- "Although we are two different faculties within the law school, we have spelled out a few instances where law library faculty have the same rights as law faculty: acceptability and recommendation votes on the law library director and law school dean; votes for representatives of the faculty committee; votes for law school representatives on university committees."

- "Years ago the law faculty recognized a small separate 'law library faculty,' which was subsequently recognized by the Provost. We have a separate librarian P\&T policy which was modeled after the law faculty's policy, and the university faculty handbook."

ๆ34 Because academic law libraries are small in comparison with general academic libraries, ${ }^{51}$ law libraries may be less equipped to provide tenure-track librarians with support and mentoring during the tenure process. ${ }^{52}$ Law librarians can often find themselves in situations where there are too few colleagues available to undertake the peer review required in tenure systems. ${ }^{53}$ In these cases, law libraries need to choose between modifying the review process so that it involves fewer people, and resorting to outside reviewers. A library may determine that it is important to use outside reviewers in any case. ${ }^{54}$ Potential reviewers might be found at other law libraries, university libraries,

\footnotetext{
${ }^{51}$ The 2009 Survey asked the fifty-six respondents to provide the number of librarians at their institutions. The average was 7.14 librarians, not counting directors.

${ }^{52}$ See generally Parker, supra note 10 (discussing mentoring and support obligations on the part of law library supervisors and directors).

${ }^{53}$ Law librarians who aspire to move up in the profession tend to move around quite a bit in order to advance, so it is conceivable that there might be more junior faculty than senior faculty in a law library at any given time. See Jonathan A. Franklin, Why Let Them Go? Retaining Experienced Librarians by Creating Challenging Internal Career Paths: Introducing the "Executive Librarian," 88 LAW LIBR. J. 352, 353 (1996). See also Malmquist, supra note 1, at 151.

54 The Association of Research Libraries (ARL) provides extensive guidance for developing and implementing external review procedures. TRACY BICKNELL-HOLMES \& KAY LOGAN-PETERS, SPEC
} 
or possibly even among the law teaching faculty, although arguably the law teaching faculty might only be capable of reviewing scholarship, teaching, and service, and not librarianship. In light of the fact that law libraries favor creating small law library faculties rather than casting their lot with the university's academic librarians, it would be useful for the library faculty to explore further who serves as reviewers in their systems.

ๆ35 Also, as seen from the comment above that mentioned voting rights, there can be questions of whether law librarians should have voting privileges at law faculty meetings. If law librarians are on a university librarian track, there is little basis for claiming a vote at a law faculty meeting. But if librarians are on a law faculty track, the argument for voting privileges is stronger. The separate, law-librarian faculty track falls into a gray area. These tracks are typically created by the law school, so librarians could arguably claim a right to vote at law faculty meetings, except perhaps on law faculty promotion, retention, and tenure votes. Conversely, rational arguments can also be made to deny librarians votes at law faculty meetings because a separate, law-librarian faculty can be distinguished from the law teaching faculty. Questions concerning voting status should be anticipated, and the answers clarified in policy documents when a law school creates a separate law-librarian faculty and tenure track. ${ }^{55}$

\section{Factors Considered in Reviewing Law Librarian Tenure Candidates}

\36 To receive tenure, one must demonstrate a high level of competence, if not excellence, in an array of areas identified by the institution as relevant factors by which

KIT 293: EXTERNAL REVIEW FOR PROMOTION AND TENURE (2006), available at http://www.arl.org/bm doc/spec293web.pdf.

${ }^{55}$ For an excellent overview of the classes of voting rights within law faculties including clinicians, writing teachers, and librarians, see Susan P. Liemer, The Hierarchy of Law School Faculty Meetings: Who Votes?, 73 UMKC L. REV. 351 (2004). 
performance can be measured. The dilemma for librarians seeking to set standards for attaining tenure has always been what factors to include and how high to set the bar for candidates.

937 AALL and ACRL both recommend that librarian tenure policies reflect the same processes that are in place for reviewing the teaching faculties at their institutions; ${ }^{56}$ however, only ACRL has recommended performance standards for reviewing librarian tenure candidates. ${ }^{57}$ Tenure policies for academic librarians typically include the following factors for reviewing performance: librarianship; research and publishing; service to the institution, the profession, and possibly the community; and promise for continued excellence in the future. ${ }^{58}$ These factors reflect the ACRL Guideline recommending that "performance, scholarship, and service" be considered when reviewing tenure candidates. ${ }^{59}$ In this manner, a librarianship requirement is typically substituted for the teaching requirement found in policies governing teaching faculties. ${ }^{60}$ \38 Law librarian performance review standards are similar to those in use for most academic librarians in that librarianship is an almost-universal performance review

\footnotetext{
${ }^{56}$ The AALL resolution in favor of tenure or continuous appointment status explicitly states that librarians "should go through a similar process of evaluation and meet appropriate standards for appointment, promotion, and the grant of related benefits ...." AALL Resolution on Faculty or Academic Status, supra note 18, at 831. "Appointment of librarians shall follow the same procedures that are established for appointing all institutional faculty members." ACRL Guideline, supra note 4, at I.A.1.

${ }^{57}$ ACRL Guideline, supra note 4, at II.

${ }^{58}$ Any Internet search engine will deliver any number of library promotion and tenure policies that reflect the ACRL recommendations; however the concept of achieving excellent is often implicit. Works that explicitly discuss the "excellence" requirement to achieve tenure exist. See, e.g., Linda L. Carroll, Tenure and Academic Excellence, Academe Online (May-June 2000) http://www.aaup.org/AAUP/pubsres/academe/2000/MJ/Feat/carr.htm

${ }^{59}$ ACRL Guideline, supra note 4, at III.B.

${ }^{60}$ Interestingly, a number of academic libraries also evaluate the teaching performance of librarians. In a 1993 survey, $47.2 \%$ of college and university library respondents indicated teaching activities were considered in reviews. Park \& Riggs, supra note 12, at 76.
} 
standard. However, there are variations and inconsistencies in the other factors that are used as described in detail below.

ฯ39 The 2009 Survey asked respondents to describe performance factors that are considered when awarding tenure or continuous appointment to their law librarians. Librarianship, or job performance, was reported as a factor by nearly all respondents at $98.2 \%$ (55 of 56 answers). ${ }^{61}$ A very close second was service at $91.1 \%$ (51 of 56). Third was a category described as scholarship, research, or publishing at $85.7 \%$ (48 of 56). ${ }^{62}$ Teaching was fourth, considered by $44.6 \%$ of respondents ( 25 of 56 ). This is notable given that these standards are applied to nondirector law librarians who presumably would not be required to teach as much as law library directors. However, it was not always clear from the survey results whether teaching is treated as a separate factor, or if it is considered to be a specialized service under librarianship; both approaches were evident in the survey results. Finally, $14.3 \%$ ( 8 of 56) reported other factors are also considered (see figure 4).

\footnotetext{
${ }^{61}$ This figure should probably be $100 \%$. It appeared that the sole respondent who did not report librarianship as a factor may have misinterpreted the question; however, the author included the data in the survey as it was reported.

${ }^{62}$ This result is similar to data reported in the Texas Tech survey. See Blackburn et al., supra note 1, at 140, ๆ 31 .
} 


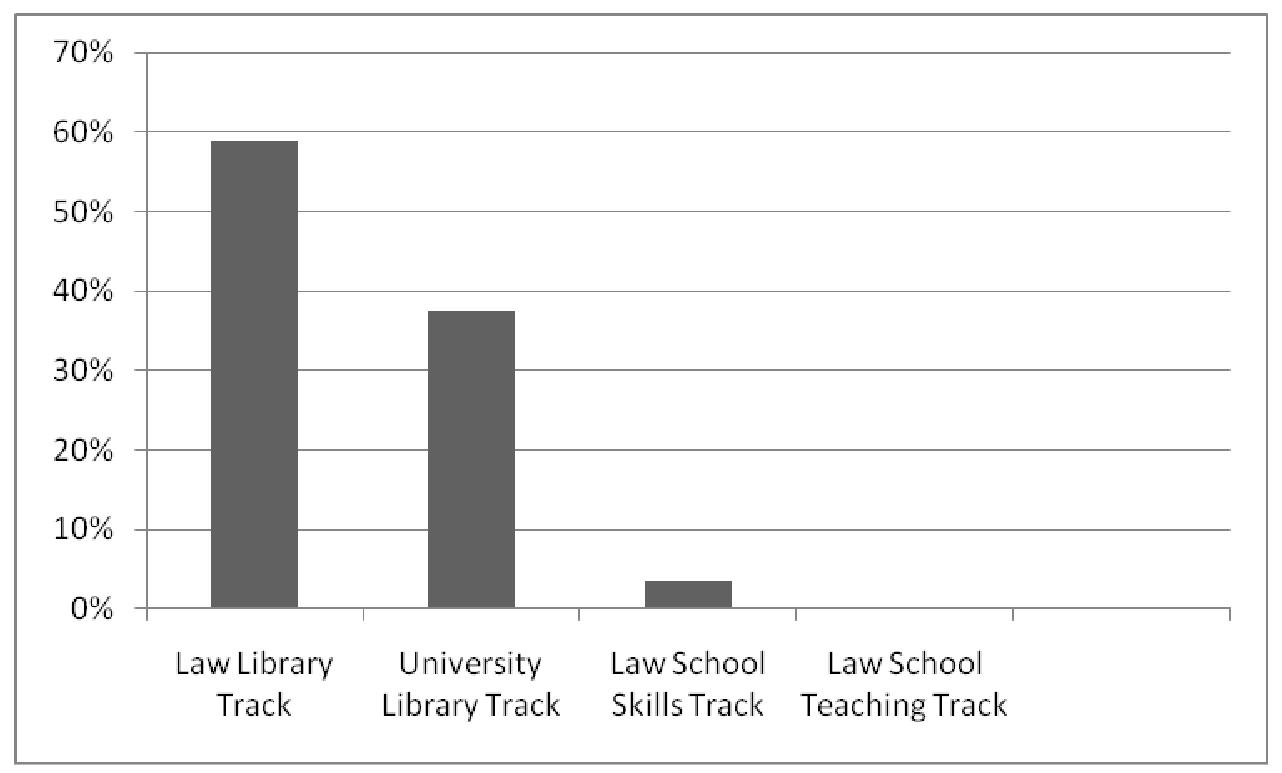

Figure 4. $98.2 \%$ of survey respondents use librarianship or job performance as a factor in tenure reviews; $91.1 \%$ review service; $85.7 \%$ review scholarship; $44.6 \%$ review teaching; and $12.5 \%$ use other factors.

『40 The 2009 Survey also revealed two basic approaches with respect to combinations of factors used: ${ }^{63}$

(1) $44.64 \%$ of respondents review performance on the basis of librarianship, scholarship, teaching, and service (25 of 56); and

(2) $37.5 \%$ review performance on the basis of librarianship, scholarship and service, but not teaching (21 of 56).

(3) In hindsight, it is unfortunate that when AALL adopted its 1987 resolution in support of tenure for law librarians, it did not also recommend specific factors for evaluation of law librarians. The resolution simply states that "evaluative criteria should reflect

${ }^{63}$ One interesting variation on the basic theme was an either or approach: "Librarianship/Job Performance is required. Two of the other three [scholarship, teaching, service] are required." Only three respondents indicated librarianship or job performance alone was considered; these three libraries confer only forms of continuous appointment. 
the unique responsibilities of law librarians in the academic mission of the law school." ${ }^{64}$ However, it is likely that variations in law library review standards among various institutions were already well entrenched at the time the resolution was adopted, and that the resolution simply reflected the realities of existing practices.

\section{Challenges Associated with Performance Review Standards}

\section{Librarianship Standards}

q41 As already noted, the 2009 Survey revealed that virtually all respondents use librarianship as a major factor when determining whether to retain, promote or award tenure to law librarians. This is consistent with data from previous surveys of both law librarians and general collection academic librarians. ${ }^{65}$

ף42 In setting performance review standards, the obvious distinction between what librarians and teaching faculties do in their respective roles must be a prime consideration. Few institutions are willing to give librarians a free pass on their job performance as librarians, meaning few would review librarians solely on the basis of scholarship, service, and possibly teaching. Almost all want librarianship to be an important factor in the review process. ${ }^{66}$ But challenges exist when trying to evaluate librarianship as a performance factor.

I43 Beyond serving the needs of law faculties and students, public services law librarians may be expected to serve secondary patron populations including lawyers and judges, faculties and students from other educational institutions, paralegal programs,

\footnotetext{
${ }^{64}$ AALL Resolution on Faculty or Academic Status, supra note 18, at 831-32.

${ }^{65}$ See, e.g., Park \& Riggs, supra note 12, at 75 (95\% of survey respondents used librarianship as a review factor).

${ }^{66}$ See Donovan, supra note 3 , at 391-92.
} 
government and court system employees, and members of the general public. Often these service demands require that law librarians provide robust, expert support for law faculty research and scholarship, provide legal research instruction to law students, and at the same time serve pro se patrons effectively and with sensitivity.

ף44 Other librarians become highly skilled specialists perhaps focusing on collection development; developing subject specializations like foreign law, international law or American Indian law; or developing expertise in technical services, electronic services, instructional technology support or web page development.

q45 Alternatively, there may be too few librarians available to permit specialization within a library, resulting in some librarians being called upon to perform multiple roles. This can lead to expectations that a law librarian should be able to demonstrate competence, if not excellence, in multiple areas of librarianship in order to attain tenure. It can also lead to assigning weights to different performance factors. This is sometimes seen in libraries that require excellent performance in two out of three or four factors, with merely a good effort necessary for the remainder.

ף46 Another challenge associated with "librarianship" as a performance review standard in tenure policies is how best to define the term. Fortunately, the investment made by AALL in developing its statement of Competencies of Law Librarianship could yield additional dividends in this context. The AALL statement of competencies could serve as a national standard to define what constitutes excellent librarianship in promotion, retention, and tenure policies ${ }^{67}$ Referencing the AALL competencies in these 
policies would give law libraries a uniform benchmark for measuring librarianship performance. The competencies statement is updated periodically, so incorporating it by reference as a policy benchmark would allow policy documents to stay current and eliminate the need for libraries to continually update policy documents as librarian roles evolve over time. Law libraries using university-wide library policies could reference the AALL Competencies to define "librarianship" through use of separate explanatory documents or appendices.

I47 The AALL competencies statement is flexible enough to recognize that some law librarians are required to demonstrate specialized knowledge, skills, and abilities in certain specialized areas such as library management, reference, research and patron services, information technology, collection development, care and management, and teaching. The AALL competencies recognize these additional roles in separate sections on specialized competencies. ${ }^{68}$

\48 The approach taken by the AALL in treating teaching as a specialized competency also shows potential as a means to treat teaching more consistently in librarian retention, promotion and tenure policies. Treating teaching as a specialized competency of librarianship, rather than treating it as a separate factor in tenure policies, would eliminate much of the inconsistency that currently surrounds the use of teaching as a tenure review standard. Teaching would simply be regarded as another specialized competency of librarianship. This proposal is discussed in more detail in the section below on Teaching Standards.

\footnotetext{
Am. Ass'n of Law Libraries, Competencies of Law Librarianship, (rev. 2010), ${ }^{68} I d$. http://www.aallnet.org/prodev/competencies.asp.
} 


\section{Scholarship Standards}

ף49 Production of scholarly written communications should be a universal requirement for any academic librarian who seeks to attain tenure, since it is the one thing that all academic disciplines have in common.

950 Some critics of tenure for librarians point to the mastery of skills associated with librarianship as being inferior and unworthy of tenure and not requiring academic freedom. ${ }^{69}$ This skills argument is a bit of a red herring, because it is uncontroversial for faculty members in other disciplines involving mastery of skills to have opportunities to attain tenure. ${ }^{70}$ More persuasive, though, is the sense that the combination of administrative and service roles with librarians' more traditionally academic roles dilutes the need for the protections of tenure. Librarians should recognize this reality and work to overcome this prejudice by making meaningful contributions to the profession though traditional academic roles such as publishing scholarly writings. The more law librarians publish, the more likely they are to gain or retain acceptance of the principle that law librarians are entitled to hold faculty and tenured status. Such efforts will ensure librarians' contributions to the shared enterprise of legal education warrant faculty status, and the protections of academic freedom and tenure.

951Daniel Ring said this about librarian scholarship and its relationship with faculty status more than three decades ago:

Faculty status for librarians has always implied a commitment to scholarship .... because it is so clearly separate from the task and service aspects of librarianship, it places librarians on a common basis

\footnotetext{
${ }^{69}$ Huddleston, supra note 2, at 38-39.

${ }^{70}$ Barbara Bintliff brought this point home when observing that dancers and sculptors are accepted as faculty members as a matter of course, while librarians are often not. Bintliff, supra note 34, at 132.
} 
with teaching faculty, and it provides them the opportunity to view their positions as something more than nine-to-five jobs. Indeed, it would be no exaggeration to say that unless librarians do engage in scholarship, they are not truly faculty members. ${ }^{71}$

During the intervening years, few have said it better.

\52 Compared to teaching faculty, librarians carry heavier service and

administrative burdens. Law librarians typically are expected to be at the library at least thirty-five or forty hours a week, twelve months a year, providing service as part of the shared enterprise of operating a library. More challenging still, librarians are rarely fully in charge of their schedules. Serving law faculty, students, and frequently the public, means that librarians must often make time for patrons at a moment's notice. This situation is quite unlike the experience of teaching faculties whose schedule is much more fully under their control. For teaching faculties, being on a tenure-track resembles undergoing a program of intensive academic study_requiring much work, but doable with dedication and good time management skills. In contrast, librarians' time management plans often are disrupted without warning by suddenly having to put the needs of others ahead of their own. ${ }^{72}$

ף53 This dilemma leads to the argument that some adjustment in the tenure requirements for librarians is in order. As James Donovan said on this point:

\footnotetext{
${ }^{71}$ Daniel F. Ring, Professional Development Leave as a Stepping Stone to Faculty Status, 4 J. ACAD. LIBRARIANSHIP 19, 19 (1978).

${ }^{72}$ My thanks to Michelle Rigual for this observation, which was based on comparing the tenure-track experiences of family members who are on teaching faculties, with what she experienced while seeking tenure as a librarian prior to becoming a director. She is not the first to make this observation. See, e.g., Richard M. Dougherty, Editorial, Faculty Status: Playing on a Tilted Field, 19 J. ACAD. LIBR. 67 (1993).
} 
The challenge, then, is to make such adjustments as are necessary, but only those which are necessary. Fail to go far enough and librarians are inherently disadvantaged in the competition for academic stature; go too far and the tenure won by librarians will be regarded by teachers as being "hollow" or nominal only, failing to signify the rigorous scrutiny they had to endure themselves. ${ }^{73}$

954 The fear is that unless an appropriate balance can be found, there is a risk that libraries could "lose some very good librarians who [could be] denied tenure simply because they were not very good [at being] faculty." ${ }^{, 74}$ In any case, it seems clear it would be unfair to simply impose teaching faculty performance standards upon librarians, given what else is expected of them.

955 The challenge for the law librarian profession is to find ways to craft promotion and retention policies that adequately recognize all of the roles encompassing law librarianship, and still provide a measure of balance. Given the importance to law schools of the unique role played by academic law librarians, law libraries should give librarianship more weight than other factors during performance reviews for retention, promotion and tenure decisions. A heavy emphasis on librarianship recognizes the centrality and importance of the librarians' primary role in the efficient functioning of the law library, while still permitting other contributions to legal education to be evaluated. ${ }^{75}$

956 Scholarly research and writing can consume vast amounts of time- and require institutional support-, but publishing can be what sets academic law librarians

\footnotetext{
${ }^{73}$ Donovan, supra note 3, at 390. Some librarians view the differences between librarianship and regular teaching faculty as too vast to be bridged, going so far as to state that librarians are not educators, and that they most definitely perform procedural tasks that are nothing equivalent to what regular teaching faculties do. Freehling, supra note 2, at 891-92.

${ }^{74}$ Id. at 892 .

${ }^{75}$ Priscilla K. Shontz \&, Jeffrey S. Bullington, Tips for New Librarians: What to Know in the First Year of a Tenure-Track Position, C \& RES. LIBR. NEWS, Feb. 1998, at 85.
} 
apart from other law librarians in courts, government or private practice. ${ }^{76}$ Also, by publishing, academic law librarians can claim kinship with teaching faculties.

ฯ57 The act of writing clarifies concepts and triggers new ideas in ways that few other endeavors can. Donald Dunn argued that an obligation to publish exists for law librarians, regardless of whether faculty status or pursuit of tenure is involved. ${ }^{77}$ Adding tenure to the mix, however, certainly provides more incentive for librarians to write. What was disappointing about the results of the 2009 Survey was that it showed production of scholarship is not universally required of law librarian tenure candidates. Certainly, in comparison with general collection academic librarians and other teaching faculties, the extent to which law librarians are expected to conduct research, write, and publish as part of tenure requirements is less than clear cut.

ฯ58 If three comments appended to the 2009 Survey are any indication, law libraries vary significantly in approaches taken with respect to scholarship:

- "Scholarship, in the form of law review articles, is not stressed."

- "The scholarship requirements are very stringent."

- "Scholarship is required, but librarianship and teaching are the most important factors for us."

q59 In contrast, the standard for what constitutes research and scholarship for general academic librarians has been elevated over the years. Whereas many academic

\footnotetext{
${ }^{76}$ Scholarship is not mentioned in the AALL law librarian statement of competencies, either as a core competency or as a specialized competency. Arguably the competency statement "shares knowledge and expertise with users and colleagues" could be read as implying a requirement to publish scholarship. It should be noted that the competencies are intended to apply to all law librarians, not just to those in academic law libraries. Am. Ass'n of Law Libraries, supra note 67.

${ }^{77}$ Donald J. Dunn, The Law Librarian's Obligation to Publish, 75 LAW LIBR. J. 225, 231 (1982).
} 
librarians in the past might have satisfied research and publication requirements by writing internal bibliographies, today many have adopted standards that require at least applied research, if not original research. ${ }^{78}$

960 As a profession, law librarians should work to achieve an elevation of scholarship standards for tenure, similar to what general academic librarians have experienced over time. It is more important than ever for law librarians to distinguish themselves as scholars. As a profession, academic law librarians do themselves no favor if they accept inconsistent standards for scholarship requirements for tenure. Not only do inconsistent standards for law librarians put justification of faculty and tenure statuses at risk for all, inconsistent standards mean that the profession of law librarianship may not be advanced to the fullest. When Dunn urged law librarians to publish more than forty years ago, he argued scholarship is important for its own sake. Dunn lamented the fact that few librarians were publishing their work. He also lamented an emphasis in the literature on librarians needing to write because of the "publish or perish" phenomenon, because Dunn saw the need to publish as one of professional responsibility. ${ }^{79}$

\$61 Scholarship is important because it is the coin of the realm in the academy; it is how one gives voice to one's ideas and, in turn, has one's voice heard by other academics. In the "economy of prestige" ${ }^{" 80}$ within the academy, scholarship is how you

\footnotetext{
${ }^{78}$ Hersberger, supra note 21, at 362 (nevertheless noting that while original research might set the standard, few librarians have the time to pursue it). But see Park \& Riggs, supra note 12, at 75-76 (in their survey, scholarship was considered at the institutions of only $62.2 \%$ of survey respondents and there was additional evidence that scholarship was often not central to the review process: "The belief that librarians must publish or perish may be based on anecdotal evidence or on a few highly publicized cases, rather than established as fact.").

${ }^{79}$ Dunn, supra note 77 , at 231.

${ }^{80}$ Michael J. Madison, The Idea of the Law Review: Scholarship, Prestige and Open Access, 10 LEWIS \& Clark L. REV. 901, 905 (2006).
} 
earn your reputation and communicate ideas. If you do not publish, you are not a credible witness to your ideas. Scholarship gives ideas and arguments weight they would not have if they were merely conveyed orally, or were limited to an internal audience. Within the academy, if you want to influence or persuade, you must publish your ideas and arguments.

962 It is also important for today’s nondirector law librarians to write because it is from this cohort that the law library directors of tomorrow will emerge. It is essential that academic librarians have opportunities to master the art of writing to compete effectively for director positions that are part of the tenure-track law teaching faculty.

963 One of the challenges for the profession in the future will be to find more ways to support the scholarly initiatives of librarians. Law school administrators and law library directors must resolve to provide nondirector law librarians with time to write. In addition, law librarians must resolve to meet regularly in workshop settings to critique and encourage each other's scholarship. ${ }^{81}$ Law faculties routinely present scholarly works at conferences. This practice needs to be more widely adopted by academic law librarians, especially if they are going to hold faculty and tenured status.

ๆ64 Scholarship workshops for law librarians could be a regular part of programming offered by ALL-SIS at AALL annual meetings. A good example of what is possible is the "Conference on Legal Information: Scholarship and Teaching." Created by Barbara Bintliff as part of the University of Colorado law school's Boulder Summer Conference Series, twenty law librarians gathered at this conference in 2009 after the

\footnotetext{
${ }^{81}$ The companion piece to this article describes in detail ways directors can support librarians' pursuit of scholarship and teaching opportunities. Parker, supra note 10, at 23-27.
} 
annual CALI meeting, and again in 2010 prior to the annual AALL meeting, to present, critique and support each others' scholarship. ${ }^{82}$ The conference is not part of AALL programming, but it is a good example of the type of programming AALL should be offering. ${ }^{83}$ These types of initiatives, if sustained, will have the effect of raising expectations as to what should constitute scholarship for law librarian tenure performance standards, as well as advance the profession of law librarianship generally.

965 Of course, this is not to say that no law libraries are currently using rigorous

publications requirements to evaluate tenure candidates. A great many of them clearly do.

However, as a profession, it is important that academic law librarians work to ensure that all libraries employ more consistent standards in this regard.

\section{Teaching Standards}

\66 Law librarians have a long tradition of providing instruction in law school

settings. This tradition encompasses bibliographic instruction, information literacy

${ }^{82}$ Legal Research Instruction: Recent Developments, LEGAL INFORMATICS BLOG, http://legalinformatics.wordpress.com/2009/09/06/legal-research-instruction-recent-developments (Sept. 6, 2009, 1:29 P.M.). These workshops provide a robust means of providing feedback to librarian authors on works in progress. Several significant articles have come out of the Boulder conference to date: Duncan Alford, The Development of the Skills Curriculum in Law Schools: Lessons for Directors of Academic Law Libraries, 28 LEGAL REFERENCE SERVICES Q. 301 (2009); Paul D. Callister, Time to Blossom: An Inquiry into Bloom's Taxonomy as a Hierarchy and Means for Teaching Legal Research Skills, 102 LAW LIBR. J. 191, 2010 LAW LIBR. J. 12; Anne Klinefelter, First Amendment Limits on Library Collection Management, 102 LAW LIBR. J. 343, 2010 LAW LIBR. J. 21; Susan Nevelow Mart, The Relevance of Results Generated by Human Indexing and Computer Algorithms: A Study of West's Headnotes and Key Numbers and LexisNexis's Headnotes and Topics, 102 LAW LIBR. J. 221, 2010 LAW LIBR. J. 13; Sarah Valentine. Legal Research as a Fundamental Skill: A Lifeboat for Students and Law Schools, 39 U. BALT. L. REV. 173 (2010).

${ }^{83}$ AALL does offer a variety of programming and initiatives to support librarian scholarship, including a Publishing Initiatives Caucus (www.aallnet.org/caucus/pic/index.htm). However, most these initiatives focus on writing and publication tips rather than on providing substantive critique of works in progress. Other regular programming at AALL meetings include the AALL LexisNexis Call for Papers Awards (www.aallnet.org/about/award_call_for_papers.asp) and a Writers' Workshop hosted by the AALL/LexisNexis Call for Papers Committee (see Writers' Workshop offered at AALL 2010 Annual Meeting, StrategiC LiBRARIAN (Apr. 7, 2010), http://strategiclibrarian.com/2010/04/07/writers\%E2\%80\%99-workshop-offered-at-aall-2010-annualmeeting), both of which focus on how-to tips. 
instruction, and informal instruction that occurs regularly at the reference desk.

Increasingly, growing numbers of nondirector law librarians also teach formal law school courses, primarily in legal research skills. These courses consist both of stand-alone courses $^{84}$ and courses that integrate research with writing instruction. ${ }^{85}$ These courses are growing in number in response to perceived deficiencies in current first-year legal research instruction programs ${ }^{86}$ Consequently, law librarians are increasingly involved with teaching legal research skills in law schools. Also, more law librarians than ever hold J.D. degrees, which may lead to greater acceptance of law librarians in the classroom. ${ }^{87}$ The recent Carnegie Report ${ }^{88}$ in particular has led many schools to reevaluate the extent to which skills training is providing within the curriculum. This may signal increasing interest on the part of law schools in providing more skills instruction in the curriculum, which must also include legal research skills. ${ }^{89}$ With all of these forces at work, it should not be surprising to find that many law libraries now evaluate teaching performance during retention, promotion, and tenure reviews.

\footnotetext{
${ }^{84}$ See Nancy P. Johnson, Best Practices: What First-Year Law Students Should Learn in a Legal Research Class, 28 LEGAL REFERENCE SERVICES Q. 77 (2009) (providing example of stand-alone classes).

${ }^{85}$ Anita L. Morse, Research, Writing, and Advocacy in the Law School Curriculum, 75 LAW LIBR. J. 232, 260-62 (1982).

${ }^{86}$ Michael Chiorazzi \& Shaun Esposito, Commentaries on Hicks' "Teaching Legal Bibliography": With an Addendum by Robert Berring, 28 LEGAL REFERENCE SERVICES Q. 9, $20-21$ (2009).

${ }^{87}$ Jeff Woodmansee, Information Services Specialist at the University of Arkansas at Little Rock, posted an informal survey on legal research instruction models to the ALL-SIS listserv in 2009. Among other questions, he asked: "Do law librarians teach legal research at your school? If so, are they dual degree librarians?" Twenty-eight librarians replied with nearly all indicating that they teach legal research at their schools and that they are all dual degreed. In some instances, schools specifically prohibited nonJ.D. librarians from teaching in the law school, limiting them to tours, paralegals, and other campus groups. E-mail on file with author.

${ }^{88}$ William M. SUllivan ET Al., EdUCATING LAWYers: PrePARATION FOR THE ProfesSiON OF LAW (2007).

${ }^{89}$ For an excellent, and pithy, overview of the curricular reform movements over the years, including the Carnegie Report, see Alford, supra note 82, at 304-06.
} 
967 How to treat teaching when it is required of librarian tenure candidates appears to be an area where a variety of approaches are used. Three comments from the 2009 Survey are illustrative:

- "Teaching is part of job performance for our public services librarians."

- "Librarians may teach as adjuncts but it is outside the scope of their librarian duties; teaching may be considered scholarship or service."

- "Librarians are expected to teach at least one legal research class in the law school every academic year; often some teach more than one."

968 In these three comments alone, we see a library that expects formal classes and evaluates teaching as a separate factor; a library that treats teaching as part of job performance; and a library that equates teaching with scholarship or service because it did not otherwise have a category for it. The challenge for law librarians, then, will be to develop a more consistent strategy for reviewing law librarian teaching, rather than leaving it open to interpretation with potentially widely varying results.

I69 In the 2001 Texas Tech survey, only five of thirty-two libraries (11.6\%) that offered tenure or another form of protected academic status to law librarians required classroom teaching in the area of legal research, legal bibliography, or legal writing, in order to achieve these statuses. ${ }^{90}$ While the 2009 Survey figure on teaching is higher than this, the Texas Tech survey distinguished between formal classroom teaching and other forms of instruction, and the 2009 Survey did not. The 2009 figure may be higher because librarians are teaching more, or it may be higher because informal and formal

\footnotetext{
${ }^{90}$ Blackburn et al., supra note 1 , at 140, ๆ 30.
} 
teaching were combined in the survey results. In light of indications that librarians could be teaching more in response to the curricular reform movement, it would be useful to gather more data in this area in the future.

\70 Moving ahead, it would also be a good practice for the profession to explicitly track the different ways law librarians provide instruction in today's law schools. Unfortunately, law librarians do not yet systematically gather data on the extent to which they teach. It is thus nearly impossible to get a sense of exactly how much librarian teaching is occurring. ${ }^{91}$ Until the legal research instruction that law librarians provide in law schools is reliably tracked, law librarians can look to the Association of Legal Writing Directors' (ALWD) annual survey. The ALWD survey reports on formal librarian teaching; however, it does not capture informal librarian teaching. ${ }^{92}$ Annual ARL statistics for law libraries also capture librarian teaching activities, both formal and informal, but participation in this survey is limited to ARL-affiliated law libraries. ${ }^{93}$

『71 As noted earlier, one particular area of interest in undertaking the 2009 Survey was to inquire about faculty status for law librarians. However, with respect to whether

\footnotetext{
91 The ALL-SIS Statistics Committee proposed a supplement to the ABA annual questionnaire that includes reporting instructional services. ALL-SIS Statistics Committee, 2009 Supplemental Annual Questionnaire (June 30, 2008), http://www.aallnet.org/sis/allsis/committees/statistics/all-sis_survey063008.pdf.

${ }^{92}$ Each year the ALWD Legal Writing Institute surveys its members asking who teaches legal research at their law schools. The 2010 Survey reported that at 56 schools research is taught by librarians. At 68 schools, both legal writing faculty and librarians teach legal research. This means that at nearly $65 \%$ of respondent schools (124 of 191) law students enjoy the benefit of law librarians sharing their legal research expertise with them in the classroom, either in their own classes or together with writing instructors [up from 57\% of respondents in the 2009survey]. Of course, the ALWD survey data also means that at $40 \%$ of respondent schools (77 of 191), law librarians have no involvement in legal research instruction. Respondents were permitted to choose more than one option so there is some overlap between these two numbers. ASS'N OF LEGAL WRITING DIRS., 2010 SURVEY RESULTS, http://www.lwionline.org/uploads/FileUpload/2010SurveyResults.pdf.

93 Ass'n of Res. Libraries, Annual Surveys: Law Library Statistics http://www.arl.org/stats/annualsurveys/law/index.shtml (last visited Oct. 29, 2010).
} 
faculty status plays a determinative role in whether teaching is likely to be a performance factor, there was no clear association seen in the survey results. Among the 2009 Survey respondents whose librarians hold faculty status and can attain tenure (31 in total), there was an even split between libraries using teaching as a performance standard, and those who do not. Of the respondents whose librarians hold faculty status and can attain continuous appointment status (12 in total), eight use teaching as a factor, and four do not. Among the respondents whose librarians do not hold faculty status but can attain continuous appointment (13 in total), only three use teaching performance as a review factor. The latter figure may be the only indication of a possible association seen in the survey results - the lack of faculty status tends to be associated with the lack of a teaching requirement. The data are otherwise too mixed to discern other associations between library faculty status and the likelihood that teaching will or will not be evaluated when librarians are considered for promotion, retention or tenure.

972 As previously noted, adopting the AALL competencies as a means for defining librarianship in tenure policies would allow for treatment of teaching as a specialized competency for law librarians. This approach would avoid the necessity of treating teaching as a separate performance review factor that is distinct from librarianship. Such an outcome would eliminate many of the inconsistencies currently surrounding use of teaching as a tenure review standard by simply making teaching another specialized competency of librarianship, like collection development or electronic services. Approaching teaching in this manner would allow law libraries to move toward a national standard that is not so restrictive that it causes problems for 
librarians who do not currently teach, but is flexible enough to allow for teaching, when it occurs, to be fully and consistently evaluated.

73 Regardless of whether libraries elect to regard teaching as a specialized competency, tenure policies should clearly state that teaching roles exist for many librarians. Policies should recognize that teaching can occur both formally and informally, and clarify whether both formal and informal teaching will count, and if so, how performance will be measured. Making clear statements about librarian-provided instruction in retention, promotion, and tenure policies is important, not only for policy clarity, but also to remind law faculty members and other nonlibrarians who might read these policies of the similarities that exist between them and academic librarians.

Recognizing that librarians can and do teach in retention, promotion, and tenure policies advances the perception of librarians as "partners in the educational enterprise" 94 of modern law schools.

\section{Service Standards}

ๆ74 Nearly all of the respondents to the 2009 Survey reported using service as a factor in performance reviews for retention, promotion and tenure decisions. ${ }^{95}$ Even the handful of respondents who did not consider either scholarship or teaching in tenure reviews considered service in addition to librarianship. This is consistent with results in previous surveys of both law librarians and college and university librarians. ${ }^{96}$ Yet while

\footnotetext{
94 This phrase was used in the 1987 AALL resolution supporting tenure opportunities for academic law librarians. AALL Resolution on Faculty or Academic Status, supra note 18, at 831.

${ }^{95}$ This category was the second most used by survey respondents, after librarianship itself with $91.1 \%$ (51 of 56) reporting it as a factor.

${ }^{96}$ See, e.g., Blackburn et al., supra note 1, at 141 tbls. 11 \&12; Park \& Riggs, supra note 12, at 75 (87\% of survey respondents used institutional or professional service as a review factor).
} 
service appears to be a near-universal "third prong" in tenure policies, it occasionally appears to be used as a catch-all term to capture many different concepts. It is also often used to emphasize service to the profession via participation in professional organizations, rather than institutional or community service. ${ }^{97}$ Further, some of the survey respondents reported using the term "service" to capture "professional development," rather than service to the community, the institution, or the profession of law librarianship in the traditional sense teaching faculties would refer to service in tenure policies. And as noted earlier, some survey respondents even reported using "service" as a means to consider scholarship and teaching when those standards are not otherwise specifically required by their policies. Examples of the wide range of applications can be seen in some of the survey responses:

- "The three areas of consideration are job performance, professional development, and service."

- "Professional development includes a range of activities which includes scholarship/research \& publication."

- "They must be excellent in performance and above average in either Professional Development or Service."

- "A high quality of performance in the area of the candidate's responsibility; professional and academic achievement; and dedication to librarianship and participation in larger University affairs.”

- "Professional Competence, Professional Development, Professional Contributions."

\footnotetext{
${ }^{97}$ See Blackburn et al., supra note 1, at 141 tbl.11 (service to the profession considered as distinct from institutional or community service).
} 
975 Traditionally in tenure policies, service benefiting the institution, the community, or the profession is required of tenure candidates. There is also a clear association between this concept and faculty status. Service is part of the burden placed on a faculty member in exchange for the benefits that tenure confers. The absence of an institutional service requirement in the more traditional form of shared governance through committee work that was reported by many of the 2009 Survey respondents is noteworthy. It may partially be explained by law librarians attaining tenure or continuous appointment primarily within small law library faculties. When faculties are small, there is far less need to convene distinct committees, and thus less need for an institutional service requirement, unless it is provided at the law school or university level. Law librarians already meet regularly to collaborate and discuss day-to-day work such as reference service, faculty research support service, instructional service, and collection development. In the context of teaching faculties, such work would resemble faculty committee work and would be considered institutional service. In the context of librarians, this work is simply regarded as part of their job.

976 While that might explain the absence of an institutional service requirement on behalf of law libraries, it does not explain an absence of a requirement for service to the law school or university. There was data in the Texas Tech survey showing that law librarians who hold university faculty status are much more likely to participate in university governance activities than they are in law school governance. ${ }^{98}$ This pattern is

\footnotetext{
${ }^{98} I d$. at $142-43$, ๆศा $35-36$.
} 
consistent with indicators showing broader support for the concept of librarians as faculty within universities than among independent law schools.

\$77 Interestingly, the 2009 Survey also revealed use of a "professional development" requirement in several tenure policies. Its appearance under the "service" category of the survey, however, raises more questions than answers and merits further exploration. References to professional development are not typically seen in tenure policies governing teaching faculties, for example. Professional development, in its truest sense, is something one undertakes as a means to some other end. One engages in professional development in order to facilitate some goal, such as maintaining or enhancing one's knowledge or skills, perhaps by attending a workshop. Policies that reference professional development would do well to clarify the end goals, not just the means of pursuing these goals. In the context of librarians, the need for professional development would presumably be linked to keeping one's librarianship or teaching skills current.

978 Very likely, policies that reference professional development do clarify the end goals of the requirement, and the limited nature of the survey simply could not capture the context of the use of this term of art. Formulation of the 2009 Survey questions was heavily influenced by the three factors recommended in the ACRL tenure guidelines for librarians - performance, scholarship, and service — none of which include "professional development." ${ }^{, 99}$ Not seeing professional development as a survey option, respondents may have checked the next best choice in the survey and then added

\footnotetext{
${ }^{99}$ ACRL Guideline, supra note 4, at III.B.
} 
explanatory comments. Given more precise survey questions and categories, perhaps more consistent usage patterns among law libraries could be discerned. In any case, librarians should examine what concepts are meant by potentially ambiguous policy terms, and strive to bring clarity and consistency to the widely varying usage patterns currently seen in tenure policies.

\section{Conclusion and Recommendations}

\$79 Law libraries use a variety of tracks to award tenure; the most common being separate law library faculty tracks, with use of university librarian tracks being a close second. A tiny number of nondirector law librarians have been able to pursue tenure on a law school skills track. Regardless of the means employed, the most important thing for academic law librarians is that they also hold faculty status. Faculty status entitles librarians to participate in the shared governance of their institutions.

\$80 Law libraries today employ a variety of different performance review standards for tenure candidates. For example, while nearly all libraries require librarianship and scholarship, a third prong is often used to capture not just service to the profession, institutional, or community, but also sometimes to capture the concept of "professional development." Occasionally service is even used as a means to review scholarship or teaching when those factors are not considered separately. Scholarship is routinely, but not universally, required. Teaching is reviewed quite often—sometimes under its own category and sometimes as part of a librarianship category—but it is unclear whether or not existing policies distinguish between formal and informal teaching, and whether librarians who do not teach can also attain tenure if teaching is a 
separate requirement. As a profession, law librarians would benefit from a more rigorous exploration of how these performance standards are being employed.

981 Ideally, tenure standards across law libraries would be more uniform.

Commentators have acknowledged on numerous occasions that the greater the difference between requirements for law librarians and teaching faculties, the more likely that resistance to librarian tenure will be encountered among teaching faculties. ${ }^{100}$ Being able to point to consistently rigorous standards for law librarians — even if they are different from those of the teaching faculties - is a good way to counter arguments against tenure for law librarians, and also to prevent review criteria from potentially being skewed to such an extent they do not recognize the central role librarianship can and should play in the process.

982 Inconsistent standards can also interfere with portability of tenure once it is obtained by making it harder to determine if a lateral job candidate has met the same standards for tenure or continuous appointment that are in place at another library. Someone who currently has tenure or continuous appointment will expect to have it if they take a new position. The inconsistent standards seen in law libraries across the United States today could discourage mobility among institutions if it is "easier" to get tenure at one library than at another. Candidates whose portfolio is perceived as substandard may encounter resistance if they request similar status at a new library that employs more rigorous standards for attaining tenure.

\footnotetext{
${ }^{100}$ Because of these concerns, there are some reports of criteria for librarian promotion and tenure having little relation to the actual day-to-day work of librarians. Simon, supra note 11, at 21. 
983 Currently, if a law library seeks to implement a tenure policy where none existed before, or perhaps revise and update an existing policy, the standard operating procedure is to borrow a policy from another school or even another discipline. Thus, it is important for the profession of law librarianship to do the work of parsing out the common elements of the patchwork quilt of approaches, and forge those comment elements into over-arching guidelines and recommendations.

\$84 No professional association provides guidelines or recommendations for specific criteria for reviewing the performance of nondirector law librarians for retention, promotion and tenure decisions. In contrast, the ACRL Guidelines for general collection academic library tenure policies recommend that scholarship, librarianship, and service be used to assess candidate performance. Why the 1987 AALL resolution in support of tenure or continuous appointment did not recommend specific performance factors for use in evaluating law librarians — not even librarianship —is not obvious from the literature. The only guidance the AALL resolution provides is to state that "evaluative criteria should reflect the unique responsibilities of law librarians in the academic mission of the law school." ${ }^{\prime 101}$ The 1987 resolution should be revised to include specific factors for performance review—at a minimum, librarianship and scholarship. It should not be controversial to promote the notion that excellent librarianship and production of scholarly writings should be required in order for academic law librarians to receive tenure or a form of continuous appointment.

${ }^{101}$ AALL Resolution on Faculty or Academic Status, supra note 18, at 831-32. 
985 The work of the ALL-SIS Continuing Status/Tenure Committee has made some important contributions to the profession. Its ongoing survey of law libraries that offer tenure and continuous appointment — currently published on its web site — and its collection of policy documents, are valuable resources. However, an important next step for the profession would be to create model policy documents for libraries to consider when implementing or revising their own policies. The outcome of this work would be policies that are known to be well suited to law librarians.

986 The work of creating a model policy statement would require that law librarians clarify what is meant by terms of art such as librarianship, scholarship, service and professional development. It would require that law librarians reach a consensus about how law librarian instruction and teaching should be reviewed. Librarians should decide whether teaching or instruction should be a separate review factor, or should perhaps be regarded as a specialized competency within librarianship, as it is currently treated in the AALL law librarian competencies statement. In any case, what is important is that the rationale behind the policies implemented be clear. This information is important for prospective job candidates to know when they are considering whether or not to take a tenure-track position.

ฯ87 In addition, library leaders must work together to create more opportunities for programming at conferences that helps law librarians develop their scholarship. This type of support, if sustained, could help raise expectations as to what should constitute scholarship for law librarian tenure performance standards, as well as advance the profession of law librarianship generally. 
\$88 However, even absent new resolutions or model policy statements emerging from within professional associations, or development of new conference and workshop opportunities for librarians to present their scholarship, individual libraries can act on their own. Library directors need to ensure their policy statements reflect what should be a national standard for excellence. Tenure should be granted only after a rigorous process through which candidates demonstrate they are, and will continue to be, excellent librarians, scholars, occasionally teachers, and in general a "force for good" in carrying out the mission of the library and law school. ${ }^{102}$ If existing policies do not impose rigorous enough standards, they should be changed. Anything less than requiring librarians to publish, in addition to demonstrating excellence in librarianship, undercuts the position that tenure for librarians is warranted. Library directors also need to provide nondirector librarians with the resources and support necessary for them to engage in rigorous scholarship.

989 The observations of John Makdisi about the need not to dilute tenure requirements—although written regarding law library directors—are equally relevant to a discussion of tenure requirement for nondirector academic law librarians:

There is no way that you can promote what is necessary for the future of legal education unless you understand it at the very core: You are not going to have this degree of understanding unless you know what scholarship is like from the inside, and you are not going to know how to promote it unless you have actually taught and participated in the governance of a school. ${ }^{103}$

\footnotetext{
102 The "force for good" reference is how one commentator described the need for collegiality within a library setting. Philip C. Howse, Perspectives on ... Collegiality, Collegial Management, and Academic Libraries, 29 J. ACAD. LiBRARIANSHIP 40, 42 (2003). See Parker, supra note 10, at 15-20 for in-depth discussion of the role of collegiality in the tenure process.

${ }^{103}$ Makdisi, supra note 45, at 433.
} 
990 Law librarians, as faculty members and academic professionals, should embrace opportunities to engage in faculty governance, write, teach, and provide institutional and professional service, because of the personal, professional, and institutional benefits that flow from this work. Their policies should reflect these worthy goals. 


\section{Appendix: Survey of Academic Law Library Directors}

1. Is your law school part of, or affiliated with, a university?

Yes No Comments

2. Name of your law school library:

3. How many law librarians work at your institution, not counting the director?

4. Law librarians (non-directors) at your institution hold faculty status, and thus are afforded protections similar to those provided to regular teaching faculties through a faculty governance policy or policies:

Yes No Comments

5. Law librarians at your institution are able to pursue:

Tenure

Continuous Appointment

Other equivalent (please describe in comment)

Comments

6. Law librarians at your institution attain tenure or continuous appointment through:

Law School regular teaching faculty track

Law School other faculty track (practical, skills, clinical, or equivalent)

Law Library (librarians as a separate faculty)

University librarian track

Comments

7. Law librarians at your institution are required to demonstrate competence or excellence in the following areas in order to attain tenure or continuous appointment (please check all that apply):

Librarianship/Job Performance

Scholarship/Research/Publication

Teaching

Service

Other (please describe)

Comments

8. How many years does it normally take a law librarian to attain tenure or continuous appointment at your institution?

$1-3$

4

5

6

$6+$

Comments 
9. If a law librarian fails to attain tenure or continuous appointment at your institution, how many appeals are available and to whom (please check all that apply)?

Law School Dean

Provost

University Faculty Senate Committee

Board of Trustees/Regents

University President

Other (please explain)

10. If your law school is part of, or affiliated with, a university, are the librarians at other university libraries eligible for tenure or continuous appointment?

Not applicable

Yes

No

Comments 